\title{
Tests of a Four-Factor Asset Pricing Model: The Stock Exchange of Thailand
}

\author{
Sasipa POJANAVATEE ${ }^{1}$
}

Received: July 03, 2020 Revised: July 25, 2020 Accepted: August 10, 2020

\begin{abstract}
The objective of this study is to examine whether the four-factor model explains variation in the expected return of stocks on the Stock Exchange of Thailand. The study used individual monthly data for all stock with continuous trading on the Stock Exchange of Thailand. The study used sample data of 429 listed stocks to construct 8 portfolios bases on the industries. In this study, subject to market factors such as size, the book-to-market ratio, the market beta, and stock liquidity are taken into account. The Empirical analysis reveals that not all of the variables included in the four-factor asset pricing model are statistically significant to do affect the formation of the rate of return on stocks calculated on a monthly basis. The result shows that market beta, stock liquidity, and the book-to-market ratio has a significant increase in the rate of return on shares listed on the Consumer Products. It is therefore apparent that at least in respect of monthly analysis, the predictions of bass models in the field of modern finance theory systematic risk measured by the beta coefficient did play a significantly important role in the formation of the rate of return on the Stock Exchange of Thailand.
\end{abstract}

Keywords: Liquidity Risks, Pástor and Stambaugh Model, Stock Returns, Thailand Stock Exchange

JEL Classification Code: G12, G13, G14

\section{Introduction}

The role of market factors in empirical finance has grown rapidly over the past four decades influencing conclusion in asset pricing. Many of study in this area implement the market factors and fundamental variables, such as market beta, firm size, the book-to-market ratio, dividend yield, and momentum on the stock to explain of the variability of stock market returns(Acheampong \& Swanzy, 2015; Lau, Lee, \& McInish, 2002; Shaharuddin, Lau, \& Ahmad, 2018). In recent times, however, the empirical studies find liquidity risk plays an important role in the research of asset pricing(Acharya \& Pedersen, 2005; Chordia, Roll, \& Subrahmanyam, 2000; Vu, Chai, \& Do, 2015).However, the knowledge of liquidity risk

${ }^{1}$ First Author and Corresponding Author. Assistant Professor, Department of Cooperatives, Faculty of Economics, Kasetsart University, Thailand [Postal Address: 50 Ngamwongwan Road, Chatuchak, Bangkok, 10900, Thailand] Email: Sasipa.poj@ku.ac.th

(c) Copyright: The Author(s)

This is an Open Access article distributed under the terms of the Creative Commons Attribution Non-Commercial License (https://creativecommons.org/licenses/by-nc/4.0/) which permits unrestricted non-commercial use, distribution, and reproduction in any medium, provided the original work is properly cited. on the abovementioned studies limited to empirical evidence from individual stock exchanges (e.g., the U.S., Hong Kong, China, and Australia). More importantly, empirical results based on previous studies are not conclusive. The seemingly conflicting empirical findings in the literature suggest that more work is needed. This limitation means that many important questions remain unanswered and new data must be used to test the validity of liquidity risk in different economies. Moreover, Pástor and Stambaugh model has not been tested with data from the Thai market. This study extends the literature on asset pricing by providing updated results of the Pástor and Stambaugh liquidity model that can be used as a reference point for researchers, portfolio managers, and individual investors. The primary objective is to investigate the role of liquidity risk as an additional factor in the three-factor asset pricing model (Fama \& French, 1993). This study presents a Pástor and Stambaugh (2003) model that helps explain how asset prices are affected by market beta, size, value, and liquidity.

The remainder of this study is organized as follows. Section 2 discusses the relevant literature and Section 3 discusses the specific model to explain the impact of variables on the rate of return and data. Section 4 discusses 
empirical results. Finally, Section 5 provides a summary of the findings and policy implications.

\section{Literature Review}

In standard assets pricing theory, expected stock returns are related cross-sectionally to return's sensitivities to market factors. The traditional asset pricing model, formally known as the Capital Asset Pricing Model (CAPM), uses only excess return (RM) of a market portfolio to describe the returns of a portfolio (Lintner, 1965; Mossin, 1966; Sharpe, 1963). Another model commonly used in portfolio asset pricing is the three-factor asset pricing model (Fama \& French, 1993) where the average portfolio returns are explained by adding two factors to CAPM to reflect a portfolio's return - stock's size and stock's book - to market ratio. The empirical evidence provided further motivation for research into other models of asset pricing that might successfully explain more the rate of returns (Amihud, 2002; Carhart, 1997; Dimson \& Mussavian, 1998; Fama \& French, 2012). Liquidity is one of many factors that investors can choose to target. This is because the liquidity factor can explain the relationship between the profitability of the company and the company's liquidity. As a result, the investigation of fundamental variables in the analysis of liquidity management has emerged. For example, AlHomaidi, Tabash, Al-Ahdal, Farhan, and Khan (2020) found a firm size, leverage ratio, and return on asset ratio effect in explaining the firms' liquidity of Indian listed firms, Camba and Camba (2020) examined the cointegration and causality analysis of dynamic linkage between stock market liquidity and economic growth in the Philippines. They found that the long-run equilibrium of stock market liquidity is cointegrated with the economic growth. In the short-run, the results indicated that economic growth is determined by the stock market liquidity.

The point of liquidity risk began to be included in the financial models introduced by Amihud and Mendelson (1986b), who study the relationship between liquidity and returns. They used the bid-ask spread as a proxy for liquidity, they found the less liquid stock has a higher average return. Other studies confirmed that after controlling for size, book-to-market, and other variables, liquidity remains as a significant impact on the stock rate of return. Datar, Y. Naik, and Radcliffe (1998) found that a measure of share turnover is strongly related to future stock performance. The results show that stocks with low share turnover generate high risk-adjusted returns. Pástor and Stambaugh (2003) show that a market-wide illiquidity factor is important for explaining the cross-section of stock returns in the U.S. stock market. Acharya and Pedersen (2005) developed the stock level liquidity measurement, which bases on sensitivities to an underlying illiquidity factor, and show that there is significant positive effects on the relationship between liquidity risks and stock returns in the U.S. stock market over the period 1962-1999. Lam and Tam (2011) examined the four-factors model of 769 companies, suggested that the three-factor model combined with liquidity is explained as the relationship between the rate of return and risk is superior to the momentum factor. They also found a positive relationship between liquidity risks and stock returns in the Hong Kong markets. Ho and Chang (2015) confirmed that there is a statistically significant positive effect at significance level of liquidity risk on stock return in the Shanghai stock market.

Other studies have found evidence against a positive relationship between liquidity risk and asset pricing. Chordia, Subrahmanyam, and Anshuman (2001), and Chang, Faff, and Hwang (2010) found a negative and strong relationship between liquidity volatility and expected stock returns in the U.S. and the Japanese markets, respectively. On the Australian stock market, Marshall and Young (2003) found a statistically significant negative relationship between stock return and the liquidity (turnover rate). Shakatreh (2020) examined the effect of liquidity risks at a stock return on the Amman Stock Exchange by 52 industrial companies over the period 2014-2019. The result shown that there is a statistically significant negative effect of liquidity risk on stock return. Wang and Di Iorio (2007) found a weak effect of liquidity on stock returns in the Chinese stock exchanges over the 1994-2002 period in respect of monthly analysis. Consistent with Narayan and Zheng (2011) used daily data during the period 1997-2003 and found that there is not a statistically significant negative effect of liquidity risk on stock return in the Chinese stock exchanges.

With regards to Thailand literature, there is a few number of researchers investigating the fundamental factor explains variation in expected returns of stocks on the Stock Exchange of Thailand. For example, Janutai and Chansom (2014) suggested that energy securities have the same direction of movement when the market is consistent and the rate of return of a small group is higher than that of the big securities group. Furthermore, the rate of return from portfolios that has a high ratio of book to market will be higher than that of the low ratio of book to market securities. Therefore, the result reveals that market beta is significantly related to positive relationship for all securities. Pusuwanaratana and Tachasermsukkul (2017) find that the CAPM model has better explanatory power than that of the three-factor model in explaining returns in the Thai market. Accordingly, CAPM can forecast the excess rate of return from $40.88 \%$ to $81.04 \%$. On the other hand, the three-factor model can forecast the excess rate of return from $73.65 \%$ to $86.96 \%$. Following the three-factor model of Fama and French (1993), Pojanavatee and Khuppakun (2019) shown that the size, value, and market beta factors do affect the 
formation of the rate of return on Property \& Construction stocks over the 61 securities from July 2015 to June 2018.

\section{Research Methods}

\subsection{Data}

The dataset used in this study is obtained from the Stock Exchange of Thailand (SET). The study uses individual monthly returns for all stock traded on the SET over the period of January 2014 to December 2018. The average monthly return of the market consisting of all stocks in the SET index are calculated as a benchmark. For the risk-free rate of return, the study selects 30 days Thai Treasury bill rate. Excess return is calculated by subtracting the risk-free rate of return from the market return. Given the total of 429 stocks, the study constructs 8 portfolios follow by industry group.

\subsection{Model Specifications}

In the academic literature, there are several liquidity measures such as the bid-ask spread (Amihud \& Mendelson, 1986b; Marshall \& Young, 2003), number of transactions (Jones, Kaul, \& Lipson, 1994), trading frequency (Ding \& Lau, 2001), However, the use of trading volume and turnover rate as the measure for liquidity is the most common (Amihud, 2002; Chan, Hong, \& Subrahmanyam, 2008; Lee \& Swaminathan, 2000; Wongchoti \& Pyun, 2005). This is because the use of turnover rate, as shown by Amihud and Mendelson (1986a), has a strong theoretical footing since, in equilibrium, liquidity is correlated with trading frequency.

The aim of the study is to determine whether there is a statistically significant relationship between variables and the evolution of the rate of return. In this study, subject to market factors such as size, the book-to-market ratio, the market risk, and stock liquidity are taken into account. In the four-factor model, proposed by Pástor and Stambaugh (2003), the asset pricing model can be expressed as:

$$
\begin{aligned}
R_{i, t}= & \alpha_{i, t}+\beta_{R M} R M_{t}+\beta_{S M B} S M B_{t}+\beta_{H M L} H M L_{t} \\
& +\beta_{I L L I Q} I L L I Q_{t}+\varepsilon_{i, t}
\end{aligned}
$$

where $R_{i, t}$ is the excess return of stock $i$ at time $t, R M$ is the excess return of a market index above the risk-free rate and $S M B$ factor is the difference between the return on a portfolio of small stocks and the return of a portfolio of large stock (small-minus-big), HML factor is the difference between the returns on a portfolio of high book-to-market stocks and the return on a portfolio of low book-to-market stocks (high-minus-low), and ILLIQ is the illiquidity factor. The study uses the turnover rate as a proxy for liquidity.
The turnover rate is defined as monthly volume divided by number of shares outstanding. Volume and the number of shares outstanding data for each company was collected on a monthly basis. $\varepsilon_{i, t}$ is residual of the regression model. $\beta$ are factor sensitivities (slope coefficient in regression) of the four independent variables RM, SMB, HML and ILLIQ. $\alpha_{i}$ is intercept of the regression line.

\subsection{Hypotheses}

Past evidence of excess rate of return leads the current study to conclude that results are inconclusive concerning the relationship excess rate of return and fundamental variables. Therefore, the following research hypothesis is formulated:

H1: There is a statistically significant relationship at the level $(\alpha \leq 0.05)$ between the excess rate of return and fundamental variables (RM, SMB, HML and ILLIQ) when there are considered together.

\section{Results and Discussion}

Given the large number of stock - a total of 429 stocks the study constructs 8 portfolios following the Thai industry. Table 1 shows the number of sample stocks used in each of the 8 portfolios constructed for each industry. As observed, Consumer Products portfolios has a total of 31 stocks which is similar to the number of the Technology portfolios. In the case of the number of shares, the four portfolios Agro \& Food, Financials, Industrials, and Services have stock of 37, 51, 67, and 81, respectively. The portfolio with the largest number of shares is Property \& Construction, with 102 shares, while the portfolios with the least number of stocks are Resources, with 29 stocks. Therefore, the summary statistics of these portfolios are also reported in Table 1.

From Table 1, the average returns show that the return from the Agro \& Food Industry portfolio underperformed the entire portfolios constructed. AGRO has the lowest portfolio with a negative average return. Among the entire portfolios, the Financials portfolio has a higher average return (0.0078), followed by Services and Technology (0.0076). In case of the portfolio excess return, the difference between the highest rates of excess return with the lowest rate of excess return appears as a small cap. Therefore, the entire portfolios have negative mean value and the lowest average rate of excess return belongs to the Agro \& Food Industry and Technology, with -1.512 . As the results, the average rate of the excess return for a sample dataset during the period of study has a negative mean value of -1.500 . The average rate of the excess return of the portfolios is below 0 , which could be explained by the stagnation in the export sector and domestic political instability. Moreover, the foreign factors have come back to play quite a lot on the Thai stock market movements such 
as the U.S.-China trade war, Fed policy rate hike, EU debt situation capital flows from emerging markets to the U.S. stock market. The movement of oil prices that are declining causing the Thai stock market to fluctuate heavily according to external factors.

Considering the explanatory variable as shows in Table 2 , the average rate of the excess return for the market during the period of study has a negative mean value of -1.5041 . This is because the SET Index only provided positive returns in 2016 and 2017 of $2.17 \%$ and $3.32 \%$, respectively. While, in $2014(-6.04 \%), 2015(-5.27 \%)$, and $2018(-4.75 \%)$ the returns dropped on an average decrease of $5.35 \%$. The size factor, $\mathrm{SMB}$, is negative and the mean is -0.0060 , implying that there was a size effect on the stock exchange of Thailand. Similarly, the liquidity risk factor, ILLIQ, is a negative mean value with -0.0216 , showing the presence of liquidity risk effect in the market on the average. The price-to-book value factor, HML is positive and the mean is 0.0239 per month. This implies that there is a presence of value effect on the returns on the stock exchange of Thailand.

Table 1: Basic Statistics Collected Monthly

\begin{tabular}{|c|c|c|c|}
\hline Industry & Share & Average return & Average excess return \\
\hline Agro \& Food Industry(AGRO) & 37 & -0.0004 & -1.512 \\
\hline Consumer Products (CONSUMP) & 31 & 0.0005 & -1.508 \\
\hline Financials (FINCIAL) & 51 & 0.0078 & -1.504 \\
\hline Industrials (INDUS) & 67 & 0.0053 & -1.506 \\
\hline Property \& Construction (PROPCON) & 102 & 0.0025 & -1.509 \\
\hline Resources (RESOURC) & 29 & 0.0044 & -1.507 \\
\hline Services (SERVICE) & 81 & 0.0076 & -1.504 \\
\hline Technology (TECH) & 31 & 0.0076 & 1.512 \\
\hline All Share & 429 & 0.0040 & -1.500 \\
\hline
\end{tabular}

Table 2: Basic Statistics for Risk Factors

\begin{tabular}{|c|c|c|c|c|}
\hline Risk Factors & Number & Mean & Minimum & Maximum \\
\hline Market Excess Return (RM) & 60 & -1.5041 & -2.2388 & -1.0583 \\
\hline Size (SMB) & 60 & -0.0060 & -0.0716 & 0.0586 \\
\hline Value (HML) & 60 & 0.0239 & -0.1022 & 0.1148 \\
\hline Liquidity (ILLIQ) & 60 & -0.0216 & -0.1050 & 0.0556 \\
\hline
\end{tabular}

Table 3: Pástor and Stambaugh Model Multiple Regression Results

\begin{tabular}{|c|c|c|c|c|c|c|}
\hline Industry & $\alpha$ & $\beta_{\mathrm{RM}}$ & $\beta_{\mathrm{SMB}}$ & $\beta_{\mathrm{HML}}$ & $\beta_{\text {ILLIQ }}$ & R-Squared \\
\hline Agro \& Food Industry(AGRO) & -0.0126 & $0.9939^{*}$ & 0.1703 & 0.0460 & 0.0146 & 0.995 \\
\hline Consumer Products (CONSUMP) & -0.0474 & $0.9624^{*}$ & 0.1050 & $1.1545^{*}$ & $1.6768^{*}$ & 0.984 \\
\hline Financials (FINCIAL) & $-0.0655^{*}$ & $0.9607^{*}$ & $-0.7716^{*}$ & 0.1140 & -0.1488 & 0.986 \\
\hline Industrials (INDUS) & -0.0013 & $0.9977^{*}$ & $0.6219^{*}$ & 0.1577 & 0.0248 & 0.997 \\
\hline Property \& Construction (PROPCON) & $-0.0294^{*}$ & $0.9845^{*}$ & 0.1322 & -0.0579 & -0.3288 & 0.996 \\
\hline Resources (RESOURC) & -0.0123 & $0.9954^{*}$ & 0.2058 & -0.1504 & $-0.5110^{*}$ & 0.997 \\
\hline Services (SERVICE) & -0.0096 & $0.9909^{*}$ & $0.4678^{*}$ & -0.0675 & -0.2009 & 0.995 \\
\hline Technology (TECH) & -0.0309 & $0.9842^{*}$ & $0.3425^{*}$ & 0.0519 & -0.1762 & 0.994 \\
\hline All Share & -0.0093 & $0.9934^{*}$ & 0.1047 & 0.0143 & -0.1678 & 0.995 \\
\hline
\end{tabular}

Note: * indicates significant at $5 \%$ level of significance based on t-statistics 
In this part, the empirical framework for investigation of the four-factor model explains variation in expected returns of stocks on the Stock Exchange of Thailand. Table 3 presents the regression results of 8 portfolios and all listed stocks applied Pástor and Stambaugh model.

The Pástor and Stambaugh regression results in all portfolios showed the relatively high $R^{2}$ ranging from $99.45 \%$ to $99.73 \%$. The alpha coefficients of all the 9 portfolios are negative and are not different from zero. Negative alpha indicates that all portfolio has not earned its required return during the period under consideration especially, the FINCIAL (-0.0655) and PROPCON(-0.0294) portfolios, with statistically significant at the $5 \%$ level. The market risk factor coefficients are positive and close to 1 for all portfolios, with statistically significant at the 5\% level. This suggests that the market factor is related to portfolio excess return, which increases in market factor would lead to a significant increase in excess returns in all portfolio.

For the size risk factor coefficients, they take positive value for all portfolios except FINCIAL portfolio being negative, with statistically significant at the 5\%. INDUS, SERVICE, and TECH portfolios have positive size coefficients which are statistically significant at the 5\% level. In the value factor, only CONSUMP portfolio can be found to associated with positive factor loading on the value factor indicating a direct relationship with portfolio excess returns, with statistically significant at the $5 \%$ level. However, the seven out of eight portfolios are insignificant at 5\% significance level and this suggest that the value factor is not capable of explaining the portfolio returns on the Stock Exchange of Thailand.

In the case of liquidity risk, the parameters evaluated for liquidity were not statistically significant at the $5 \%$. It means that there is no relationship between the excess rate of return and liquidity expressed by an increase in the rate of return with increasing illiquidity. However, in the case of an indicator of liquidity, this variable is important in shaping the excess return on the share of a CONSUMP company with positive relationships. With the inclusion of the t- statistic, the findings lead to the rejection of the alternative hypothesis (H1) that there is a statistically significant relationship between the excess rate of return and fundamental factors (RM, SMB, HML and ILLIQ) when there are considered together, at the $5 \%$ level of significance. The results from this study confirm the Gniadkowska-Szymańska (2017) findings, that the value factor does not affect the formation of the rate of return on stock calculated on a monthly basis. The relationships between the indicator of liquidity and the excess rate of return is not statistically significant, which is consistent with the findings of Wang and Di Iorio (2007). Consistently, with the findings in the univariate sorting analysis, the study found a positive statistically significant relationship between beta and excess rate of return.
Accordingly, it indicates the investors subjected to a higher systematic risk earn a high rate of return.

\section{Discussion and Conclusions}

The objective of this study is to examine whether the fourfactor model explains variation in expected return of stocks on the Stock Exchange of Thailand (SET). The study of a large sample data of 429 listed stocks with continuous trading on the SET for the period of January 2014 to December 2018, evaluated the relevance of Pástor and Stambaugh four-factor model in explaining the stock return variations in the Stock Exchange of Thailand. In the case of the Thai stock market, it can be stated that in the analysis based on the four-factor asset pricing model, not all the variables included in the model are statistically significant. The result shows that the systematic risk measured beta coefficient, the book value to price ratio, and an indicator of a lack of liquidity are capable of explaining only the Consumer Products of excess rate of return when there are considered together.

Based on the methodology described by Pástor and Stambaugh (2003), the relationship between the rate of return and systematically risk measured beta coefficient, the size of the company measured by capitalization, the book value to price ratio, and an indicator of a lack of liquidity for the collected data, thus the study concluded that the size, value and liquidity factors do not affect the formation of the rate of return on stocks calculated on a monthly basis. It is therefore apparent that at least in respect of monthly analysis, the predictions of bass models in the field of modern finance theory systematic risk measured by the beta coefficient did play a significantly important role for formation of the rate of return on the Stock Exchange of Thailand. Based on the findings in this study, some recommendations are made. It is recommended that equity investor and portfolio managers should embed in their operational strategies the explanatory power of market beta effects on share return. Besides, they should pay more attention to value and liquidity effects in the Consumer Products shares.

\section{References}

Acharya, V. V., \& Pedersen, L. H. (2005). Asset pricing with liquidity risk. Journal of Financial Economics, 77(2), 375-410. https://doi.org/10.1016/j.jfineco.2004.06.007

Acheampong, P., \& Swanzy, S. K. (2015). Empirical test of single factor and multi-factor asset pricing models: Evidence from non financial firms on the Ghana Stock Exchange (GSE). International Journal of Economics and Finance, 8(1), 99. https://doi.org/10.5539/ijef.v8n1p99

Al-Homaidi, E. A., Tabash, M. I., Al-Ahdal, W. M., Farhan, N. H. S., \& Khan, S. H. (2020). The liquidity of Indian firms: Empirical evidence of 2154 firms. Journal of Asian Finance, Economics, 
and Business, 7(1), 19-27. https://doi.org/10.13106/jafeb.2020. vol7.no1.19

Amihud, Y. (2002). Illiquidity and stock returns: cross-section and time-series effects. Journal of Financial Markets, 5(1), 31-56.

Amihud, Y., \& Mendelson, H. (1986a). Asset pricing and the bidask spread. Journal of Financial Economics, 17(2), 223-249.

Amihud, Y., \& Mendelson, H. (1986b). Liquidity and stock returns. Financial Analysts Journal, 42(3), 43-48.

Camba, A. C. Jr., \& Camba, A. L. (2020). The dynamic relationship of domestic credit and stock market liquidity on the economic growth of the Philippines. Journal of Asian Finance, Economics, and Business, 7(1), 37-46. https://doi.org/10.13106/jafeb.2020. vol7.no1.37

Carhart, M. M. (1997). On persistence in mutual fund performance. Journal of Finance, 52(1), 57-82.

Chan, J. S. P., Hong, D., \& Subrahmanyam, M. G. (2008). A tale of two prices: Liquidity and asset prices in multiple markets. Journal of Banking and Finance, 32(6), 947-960.

Chang, Y. Y., Faff, R., \& Hwang, C.-Y. (2010). Liquidity and stock returns in Japan: New evidence. Pacific-Basin Finance Journal, 18(1), 90-115.

Chordia, T., Roll, R., \& Subrahmanyam, A. (2000). Commonality in liquidity. Journal of Financial Economics, 56(1), 3-28. doi:10.1016/s0304-405x(99)00057-4

Chordia, T., Subrahmanyam, A., \& Anshuman, V. R. (2001). Trading activity and expected stock returns. Journal of Financial Economics, 59(1), 3-32.

Datar, V. T., Y. Naik, N., \& Radcliffe, R. (1998). Liquidity and stock returns: An alternative test. Journal of Financial Markets, 1(2), 203-219.

Dimson, E., \& Mussavian, M. (1998). A brief history of market efficiency. European Financial Management, 4(1), 91-103.

Ding, D. K., \& Lau, S. T. (2001). An analysis of transactions data for the stock exchange of Singapore: Patterns, absolute price change, trade size and number of transactions. Journal of Business Finance \& Accounting, 28(1-2), 151-174.

Fama, E. F., \& French, K. R. (1993). Common risk factors in the returns on stocks and bonds. Journal of Financial Economics, 33(1), 3-56.

Fama, E. F., \& French, K. R. (2012). Size, value, and momentum in international stock returns. Journal of Financial Economics, 105(3), 457-472.

Gniadkowska-Szymańska, A. (2017). The multifactorial PastorStambaugh model: Explaining the impact of liquidity on the rate of return based on the example of the Warsaw Stock Exchange. Equilibrium, 12(2), 211-228. https://doi.org/10.24136/ eq.v12i2.11
Ho, T.-W., \& Chang, S.-H. (2015). The pricing of liquidity risk on the Shanghai stock market. International Review of Economics \& Finance, 38, 112-130.

Janutai, T., \& Chansom, N. (2014). A study of the Fama French three-factor model in the stock exchange of Thailand case study in energy sector from 2010 to 2013. Journal of Finance, Investment, Marketing and Business Management, 4(3), 91-111.

Jones, C. M., Kaul, G., \& Lipson, M. L. (1994). Transactions, volume, and volatility. The Review of Financial Studies, 7(4), 631-651.

Lam, K. S. K., \& Tam, L. H. K. (2011). Liquidity and asset pricing: Evidence from the Hong Kong stock market. Journal of Banking \& Finance, 35(9), 2217-2230.

Lau, S. T., Lee, C. T., \& McInish, T. H. (2002). Stock returns and beta, firms size, E/P, CF/P, book-to-market, and sales growth: Evidence from Singapore and Malaysia. Journal of Multinational Financial Management, 12(3), 207-222. https:// doi.org/10.1016/s1042-444x(01)00051-2

Lee, C. M. C., \& Swaminathan, B. (2000). Price momentum and trading volume. Journal of Finance, 55(5), 2017-2069.

Lintner, J. (1965). The valuation of risk assets and the selection of risky investments in stock portfolios and capital budgets. Review of Economics \& Statistics, 47(1), 13-37.

Marshall, B. R., \& Young, M. (2003). Liquidity and stock returns in pure order-driven markets: Evidence from the Australian stock market. International Review of Financial Analysis, 12(2), 173-188. https://doi.org/10.1016/S1057-5219(03)00006-1

Mossin, J. (1966). Equilibrium in a capital asset market. Econometrica, 34(4), 768-783.

Narayan, P. K., \& Zheng, X. (2011). The relationship between liquidity and returns on the Chinese stock market. Journal of Asian Economics, 22(3), 259-266.

Pástor, L., \& Stambaugh, R. F. (2003). Liquidity risk and expected stock returns. Journal of Political Economy, 111(3), 642-685.

Pojanavatee, S., \& Khuppakun, P. (2019). The risk evaluation of SET100 using three-factor model. Veridian E-Journal, 12(5), 989-1005.

Pusuwanaratana, S., \& Tachasermsukkul, L. (2017). Testing the ability of the Capital Asset Pricing Model (CAPM) and the Fama-French threr-factor model on forecasting the return of stocks. Modern Management Journal, 15(12), 101-116.

Shaharuddin, S. S., Lau, W.-Y., \& Ahmad, R. (2018). Is the Fama French three-factor model relevant? Evidence from Islamic unit trust funds. Journal of Asian Finance, Economics, and 
Business, 5(4), 21-34. https://doi.org/10.13106/jafeb.2018. vol5.no4.21

Shakatreh, M. (2020). The effect of liquidity risks on the relationship between earnings and stock return on Jordanian public shareholding industrial companies. Journal of Asian Finance, Economics and Business, 7(4), 21-28. https://doi. org/10.13106/jafeb.2020.vol7.no4.21

Sharpe, W. F. (1963). A simplified model of portfolio analysis. Management Science, 9(2), 277-293.
Vu, V., Chai, D., \& Do, V. (2015). Empirical tests on the liquidityadjusted capital asset pricing model. Pacific-Basin Finance Journal, 35, 73-89.

Wang, Y., \& Di Iorio, A. (2007). The cross section of expected stock returns in the Chinese A-share market. Global Finance Journal, 17(3), 335-349. https://doi.org/10.1016/j.gfj.2006.05.007

Wongchoti, U., \& Pyun, C. S. (2005). Risk-Adjusted Long-Term Contrarian Profits: Evidence from Non-S\&P 500 High-Volume Stocks. Financial Review, 40(3), 335-359. 